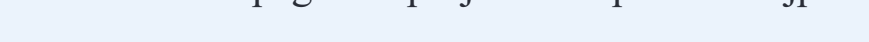

\title{
Effect of Carrageenan as Gelling Agent on Tocopherol Acetate Emulgels
}

\author{
Meiti Rosmiati*, Marline Abdassah, and Anis Y. Chaerunisaa \\ Department of Pharmaceutical Technology, Faculty of Pharmacy, Padjadjaran University, \\ Bandung, Indonesia
}

Submitted 16 October 2017; Revised 07 November 2017; Accepted 13 November 2017; Published 05 February 2018

*Corresponding author: maytearose@yahoo.com

\begin{abstract}
Vitamin E (Tocopherol acetate) is used in both oral and topical dosage. The aim of the research was to study different concentration of Carrageenan a polymer that derived from seaweed particularly Eucheuma cottonii, as a gelling agent in Tocopherol acetate Emulgels.This experimental study was initiated by emulgel formulation using different concentration of carrageenan as gelling agent, as much as $0.5 \%$ (F1), $0.75 \%$ (F2), $0.85 \%$ (F3), $0.95 \%$ (F4), 1\% (F5), 1.125\% (F6), 1.25\% (F7), 1.5\% (F8) and $2 \%$ (F9). For each formulation Tween 20 and Span 20 were used as emulsifiers (1 and $1.5 \%$ ), Liquid paraffin as oily phase (7.5\%), Propylene glycol as humectant (10\%), propyl and methyl paraben as antimicrobial preservative $(0.01 \%$ and $0.03 \%)$. The physical investigation of emulgels observed were $\mathrm{pH}$, spreading test, viscosity and freeze thaw test, that initiated with basis evaluation and then stability testing conducted for 90 days. The results showed that F5 formulation give the best physical parameters of emulgels in accordance with the requirement for topical dosage form.
\end{abstract}

Keywords: Carrageenan, emulgels, tocopherol acetate, Vitamin E

\section{Pengaruh Karagenan sebagai Bahan Pembentuk Gel pada Emulgel Tokoferol Asetat}

\begin{abstract}
Abstrak
Vitamin E (tokoferol asetat) dimanfaatkan baik dalam dosis oral maupun topikal. Tujuan dari penelitian ini adalah untuk mempelajari konsentrasi yang berbeda dari Karagenan, suatu polimer yang berasal dari rumput laut khususnya Eucheuma cottonii, sebagai Bahan Pembentuk Gel pada emulgel tokoferol asetat. Studi eksperimental ini diprakarsai oleh formulasi emulgel menggunakan konsentrasi karagenan yang berbeda sebagai bahan pembentuk gel, sebanyak $0,5 \%$ (F1), 0,75\% (F2), 0,85\% (F3), 0,95\% (F4), 1\% (F5), 1,125\% (F6), 1,25\% (F7), 1,5\% (F8) dan 2\% (F9). Untuk setiap formulasi, Tween 20 dan Span 20 digunakan sebagai pengemulsi (1 dan 1,5\%), Parafin cair sebagai fase minyak (7,5\%), propilen glikol sebagai humektan $(10 \%)$, propil dan metil paraben sebagai pengawet antimikroba $(0,01 \%$ dan $0,03 \%$ ). Sifat fisik emulgel yang diamati adalah $\mathrm{pH}$, tes penyebaran, viskositas, dan freeze thaw-test, yang dimulai dengan evaluasi dasar dan kemudian pengujian stabilitas yang dilakukan selama 90 hari. Hasil penelitian menunjukkan bahwa formulasi F5 memberikan parameter fisik emulgel terbaik sesuai dengan persyaratan bentuk sediaan topikal.
\end{abstract}

Kata kunci: Emulgel, karagenan, tokoferol asetat, vitamin E 


\section{Introduction}

Vitamin E is a lipid soluble antioxidant that is essential for the maintenance of healthy skin. Naturally occurring vitamin E is not a single compound; instead, vitamin $\mathrm{E}$ is a group of molecules with related structures, some of which may have unique properties in skin. Vitamin E is normally provided to the skin through the sebum. Topical application can also supply the skin with vitamin $E$ and may provide specific vitamin $\mathrm{E}$ forms that are not available form the $\operatorname{diet}^{1}$.

When gel and emulsion are used in combined form the dosage forms are referred as emulgel ${ }^{2}$. As the name suggest they are the combination of emulsion and gel. In recent years, there has been great interest in the use of polymers with complex functions as emulsifiers and thickeners ${ }^{3}$.

One of a carbohydrate polymers is Carrageenan that derived from seaweed particularly Eucheuma cottonii ${ }^{4}$, caraageenan has the ability to form gels in a thermoreversible waymaking it widely used as a gelling agent, thickener, and stabilizer in various industries such as food, pharmaceuticals, cosmetics, printing, and textile ${ }^{5}$. Application and use of carrageenan in the manufacture of gels and other gel products is still very limited especially for cosmeceutical products. Therefore, it is necessary to conduct a study on the effect of the concentration of gelling agent as to provide more comprehensive data related to the physical properties of the gel produced.
For this purpose carrageenan was chosen, a polysaccharide and has very interesting properties like good adhesiveness on skin which can be a benefit for topical application ${ }^{6}$. In this research, the aim study is to formulate Tocopherol acetate (Vitamin E) in emulgels, using Carrageenan as gelling agent as well as to evaluate its characteristics.

\section{Materials and Methods}

2.1. Materials

Carrageenan was obtained as a gift sample from Padjadjaran University (Bandung, Indonesia). Tocopherol Acetate (Vitamin E) (Brataco Chemical), Span 20 (Brataco Chemical), Tween 20 (Brataco Chemical), Parrafin liquidum (Brataco Chemical), Propylene glycol (Brataco Chemical), Methyl and Propyl Paraben (Brataco Chemical), Triethanol Amine (Brataco Chemical). All other chemicals used were of analytical grade.

\subsection{Emulgel Basis Orientation}

Basis selection was done by using varying amount of Carrageenan as gelling agent as much as $0.5 \%(\mathrm{~F} 1), 0.75 \%(\mathrm{~F} 2)$, $0.85 \%$ (F3), $0.95 \%$ (F4), 1\% (F5), 1.125\% (F6), 1.25\% (F7), 1.5\% (F8) and 2\% (F9). The composition of different formulations of emulgels is shown in Table 1.

2.3. Preparation of Tocopherol Acetate (Vitamin E) Emulgel

Different formulations were prepared

Table 1. Composition of emulgels base orientation

\begin{tabular}{lccccccccc}
\hline \multirow{2}{*}{ Ingredients } & \multicolumn{7}{c}{ Concentrations $(\% \mathrm{w} / \mathrm{w})$} \\
\cline { 2 - 10 } & $\mathrm{F} 1$ & $\mathrm{~F} 2$ & $\mathrm{~F} 3$ & $\mathrm{~F} 4$ & $\mathrm{~F} 5$ & $\mathrm{~F} 6$ & $\mathrm{~F} 7$ & $\mathrm{~F} 8$ & $\mathrm{~F} 9$ \\
\hline Carrageenan & 0.5 & 0.75 & 0.85 & 0.95 & 1 & 1.125 & 1.25 & 1.5 & 2 \\
Liquid Paraffin & 7.5 & 7.5 & 7.5 & 7.5 & 7.5 & 7.5 & 7.5 & 7.5 & 7.5 \\
Tween 20 & 1 & 1 & 1 & 1 & 1 & 1 & 1 & 1 & 1 \\
Span 20 & 1.5 & 1.5 & 1.5 & 1.5 & 1.5 & 1.5 & 1.5 & 1.5 & 1.5 \\
Propylene Glycol & 10 & 10 & 10 & 10 & 10 & 10 & 10 & 10 & 10 \\
Nipagin & 0.03 & 0.03 & 0.03 & 0.03 & 0.03 & 0.03 & 0.03 & 0.03 & 0.03 \\
Nipasol & 0.01 & 0.01 & 0.01 & 0.01 & 0.01 & 0.01 & 0.01 & 0.01 & 0.01 \\
TEA & 2 & 2 & 2 & 2 & 2 & 2 & 2 & 2 & 2 \\
Aqua ad. & 100 & 100 & 100 & 100 & 100 & 100 & 100 & 100 & 100 \\
\hline
\end{tabular}


using varying concentration of carrageenan as a gelling agent for tocopherol acetate emulgel. The preparation of emulsion was same in all the formulations. The gel bases were prepared by dispersing Carrageenan in heated distilled water $\left(75^{\circ} \mathrm{C}\right)$ with constant stirring at a moderate speed using mechanical shaker and adjusted to 5.5 to 6.5 using tri ethanol amine (TEA). The oil phase was prepared by dissolving certain amount of span 20 in liquid paraffin, while the aqueous phase was prepared by dissolving the required amount of tween 20 in purified water. $0.03 \mathrm{~g}$ of methyl paraben and $0.01 \mathrm{~g}$ propyl paraben were dissolved in $10 \mathrm{~g}$ of propylene glycol and both were mixed with aqueous phase. Tocopherol Acetate was dissolved in oil phase. Both the oily and aqueous phases were separately heated to $70-80^{\circ} \mathrm{C}$. Then, the oil phase was added to the aqueous phase with continuous stirring until it got cooled to room temperature. The emulsion was poured into a gel with gentle stirring until homogenous emulgel was obtained ${ }^{7},{ }^{8},{ }^{10}$.

The antimicrobial activity of methyl paraben and others is considerably reduced in the presence of nonionic surfactants, as a result of micellization. However, propylene glycol $(10 \%)$ has been shown to potentiate the antimicrobial activity in the presence of nonionic surfactants 9 .

\subsection{Evaluation of emulgel}

\subsubsection{Physical parameters of prepared for-} mulations

All the prepared formulations were visually checked for the color, appearance, homogenicity, phase separation and freeze thaw test.

\subsubsection{Determination of $\mathrm{pH}$}

The $\mathrm{pH}$ measurements were done using a digital $\mathrm{pH}$ meter (Mettler Toledo). Gel (1 g) was dissolved in $25 \mathrm{ml}$ of distilled water and the electrode was then dipped in to gel formulation until the constant reading was observed. The measurement determination of $\mathrm{pH}$ of each formulation were measured in three replicate ${ }^{7}$.

\subsubsection{Determination of viscosity}

The viscosity of each formulations was determined at ambient temperature using Brookfield digital viscometer with spindle no. 5 at $50 \mathrm{rpm}^{8}$.

\subsubsection{Determination of spreadability}

A weighed quantity $(350 \mathrm{mg})$ of emulgel was taken on a glass plate $(10 \times 5 \mathrm{~cm})$. Another glass plate $(10 \times 5 \mathrm{~cm}$ and $5.8 \pm 1 \mathrm{~g})$ was dropped from a distance $5 \mathrm{~cm}$. The diameter of the circle of spread was measured after 1 $\mathrm{min}^{8}$. Types of gels based on spreadability are given in Table 2.

\section{Results}

\subsection{Emulgel Base Orientation Result}

Based on the result in Table 3 and Table 4. Formulas F5, F6 and F7 show the beter results in consistency, phase separation, and freeze thaw test compare to formulas F1, F2, F3, F4, F8 and F9, only formulas F5, F6 and F7 have condition easy to spread and no phase separation after freeze thaw test, meanwhile F8 and F9 have no phase separation but their consistency harder and very stiff.

\subsection{Formulation Tocopherol Acetate (Vita- min E) Emulgels \\ The freeze thaw test show that the F7, formula F5 was found to be the best for formulating tocopherol acetate emulgel from}

Table 2. Types of gels based on spreadability ${ }^{11}$

\begin{tabular}{lc}
\hline \multicolumn{1}{c}{ Types of gels } & Measurment $(\mathrm{cm})$ \\
\hline Fluid gel & $>2.4$ \\
Semi-fluid gel & $1.9-2.4$ \\
Semi-stiff gel & $1.9-1.6$ \\
Stiff gel & $1.6-1.4$ \\
Very stiff gel & $<1.4$ \\
\hline
\end{tabular}


Table 3. Physical evaluation of emulgel base

\begin{tabular}{ccccc}
\hline Formulas & Color & Odor & Consistency & Phase Separation \\
\hline F1 & White & Odorless & Thinner & Separated \\
F2 & White & Odorless & Thinner & Separated \\
F3 & White & Odorless & Thinner & Separated \\
F4 & White & Odorless & Thinner & Separated \\
F5 & White & Odorless & Viscous, easy to spread & None \\
F6 & White & Odorless & Viscous, easy to spread & None \\
F7 & White & Odorless & Viscous, easy to spread & None \\
F8 & White & Odorless & Harder & None \\
F9 & White & Odorless & Harder & None \\
\hline
\end{tabular}

parameters $\mathrm{pH}$ measurement $\mathrm{F} 5$ that has $\mathrm{pH}$ values between 6-6.5, meanwhile for F6 and F7 have good stability in the concentration of Tocopherol Acetate was $5 \%{ }^{12}$. The whole Formulation can be seen in Table 5.

\subsection{Physical Stability Study of Tocopherol} Acetate (Vitamin E) Emulgels

Table 6 and figure 1 show the physical properties of the emulgels in F5, F6, and F7. The result shows that F5 has the better formula based on parameters such as $\mathrm{pH}$ measurement and spreadability test. The F5 continues to stability test and figure 2 indicating stability studies data of F5 formula.

\section{Discussion}

Nine formulations of emulgel with carrageenan as gelling agent were prepared as indicated in Table 1. From preliminary trials it was found that when carrageenan was used beyond $1.25 \%$ the gel base obtained was highly viscous making it unfavorable to used. Similarly at concentrations below $1 \%$ the viscosity was very poor. Hence carrageenan was used in the range of $1-1.25 \%$ in formulations F5-F7.

The result of various physical parameters evaluated are given in Table 3,4. Formulations F1-F4 were fluid due to the presence of low carrageenan concentrations. Formulations F8-F9 were thick due to higher carrageenan concentrations. Formulations F5-F7 have creamy appearance and no phase separation was observed at centrifugation test ant freeze thaw test.

Based on viscosity, spreadability and $\mathrm{pH}$ measurement result of formulas F5F7, formula F5 was found to be the best

Table 4. Freeze thaw test result

\begin{tabular}{ccccccc}
\hline \multirow{2}{*}{ Formulas } & \multicolumn{7}{c}{ Concentrations (\% w/w) } \\
\cline { 2 - 7 } & 1 & 2 & 3 & 4 & 5 & 6 \\
\hline F1 & $(-)$ & $(+)$ & $(+)$ & $(+)$ & $(+)$ & $(+)$ \\
F2 & $(-)$ & $(+)$ & $(+)$ & $(+)$ & $(+)$ & $(+)$ \\
F3 & $(-)$ & $(-)$ & $(+)$ & $(+)$ & $(+)$ & $(+)$ \\
F4 & $(-)$ & $(-)$ & $(+)$ & $(+)$ & $(+)$ & $(+)$ \\
F5 & $(-)$ & $(-)$ & $(-)$ & $(-)$ & $(-)$ & $(-)$ \\
F6 & $(-)$ & $(-)$ & $(-)$ & $(-)$ & $(-)$ & $(-)$ \\
F7 & $(-)$ & $(-)$ & $(-)$ & $(-)$ & $(-)$ & $(-)$ \\
F8 & $(-)$ & $(-)$ & $(-)$ & $(-)$ & $(-)$ & $(-)$ \\
F9 & $(-)$ & $(-)$ & $(-)$ & $(-)$ & $(-)$ & $(-)$ \\
\hline Note : \\
(-) No Phase Separation \\
(+) Phase Separation
\end{tabular}


Table 5. Formulation of tocopherol acetate emulgels

\begin{tabular}{lccc}
\hline \multicolumn{1}{c}{ Component } & \multicolumn{2}{c}{ Concentration $(\% \mathrm{w} / \mathrm{w})$} & $\mathrm{F} 7$ \\
\hline Carrageenan & $\mathrm{F} 5$ & $\mathrm{~F} 6$ & 1.25 \\
(Tocopherol Acetate (Vitamin E) & 1 & 1.125 & 5 \\
Liquid Paraffin & 5 & 5 & 7.5 \\
Tween 20 & 7.5 & 7.5 & 1 \\
Span 20 & 1 & 1 & 1.5 \\
Propylene glycol & 1.5 & 1.5 & 10 \\
Nipagin & 10 & 10 & 0.03 \\
Nipasol & 0.03 & 0.03 & 0.01 \\
TEA & 0.01 & 0.01 & 2 \\
Aqua ad. & 2 & 2 & 100 \\
\hline
\end{tabular}

for formulating tocopherol acetate emulgel from parameters $\mathrm{pH}$ measurement $\mathrm{F} 5$ that has $\mathrm{pH}$ values between 6-6.5, meanwhile $\mathrm{F} 6$ and $\mathrm{F} 7$ have $\mathrm{pH}$ values above 6.8 , that slightly beyond safe level for skin topical requirements which was at the range 4.56.813 . For spreadability test F5 belonged to fluid gel category, and formulations F6 and F7 with higher concentration of carrageenan belonged to semi fluid gel and semi stiff gel to stiff gel respectively. With an increase in gelling agent concentration in formulation, the spreadability of formulations decreases ${ }^{8}$. The result are reported at figure 1 .

Accelerated stability studies were performed for formulation F5 for 3 months. The samples were analyzed for 0,7,14,28.45.60 and 90 days for physical appearance, viscosity, $\mathrm{pH}$ and spreadability.
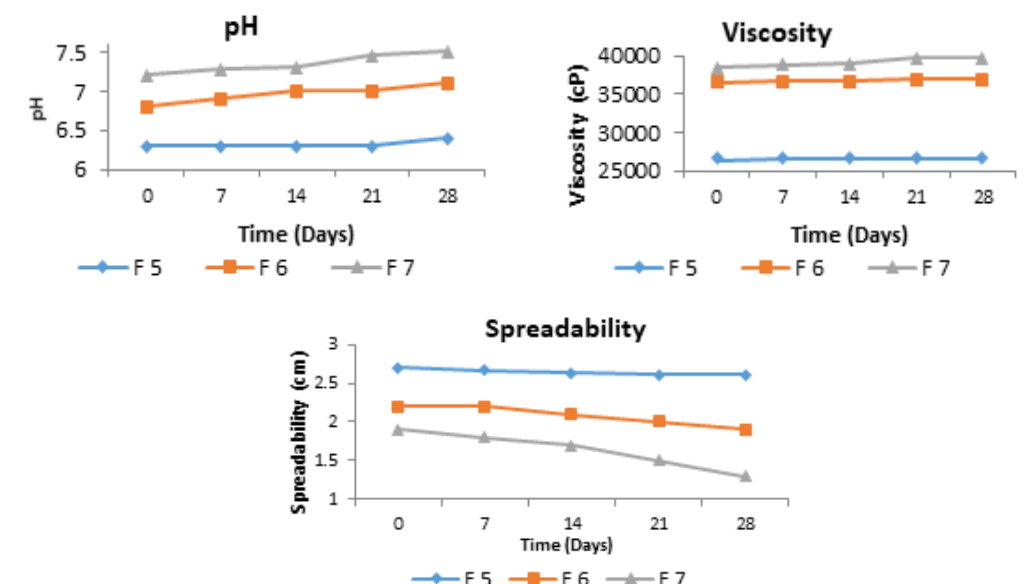

Figure 1. Evaluation of Tocopherol Acetate Emulgels Formula F5, F6 and F7 
Table 6. Physical characteristic of tocopherol acetate emulgel formulations

\begin{tabular}{|c|c|c|c|c|c|c|}
\hline \multirow{2}{*}{$\begin{array}{l}\text { Formulation } \\
\text { Code }\end{array}$} & \multirow{2}{*}{$\begin{array}{l}\text { Organoleptic } \\
\text { characteristics }\end{array}$} & \multicolumn{5}{|c|}{ Time Storage (days) } \\
\hline & & 0 & 7 & 14 & 21 & 28 \\
\hline \multirow{6}{*}{ F5 } & Phase separation & No & No & No & No & No \\
\hline & Color & White & White & White & White & White \\
\hline & Odor & Odorless & Odorless & Odorless & Odorless & Odorless \\
\hline & Texture & Smooth & Smooth & Smooth & Smooth & Smooth \\
\hline & Consistency & Viscous & Viscous & Viscous & Viscous & Viscous \\
\hline & Homogeneity & Homogenous & Homogenous & Homogenous & Homogenous & Homogenous \\
\hline \multirow{6}{*}{ F6 } & Phase separation & No & No & No & No & No \\
\hline & Color & White & White & White & White & White \\
\hline & Odor & Odorless & Odorless & Odorless & Odorless & Odorless \\
\hline & Texture & Smooth & Smooth & Smooth & Smooth & Smooth \\
\hline & Consistency & Viscous & Viscous & Viscous & Viscous & Viscous \\
\hline & Homogeneity & Homogenous & Homogenous & Homogenous & Homogenous & Homogenous \\
\hline \multirow{6}{*}{ F7 } & Phase separation & No & No & No & No & No \\
\hline & Color & White & White & White & White & White \\
\hline & Odor & Odorless & Odorless & Odorless & Odorless & Odorless \\
\hline & Texture & Smooth & Smooth & Smooth & Smooth & Smooth \\
\hline & Consistency & Viscous & Viscous & Viscous & Viscous & Viscous \\
\hline & Homogeneity & Homogenous & Homogenous & Homogenous & Homogenous & Homogenous \\
\hline
\end{tabular}

stored at climatic chamber then the viscosity value will be lower because of the influence of the high humidity so that the preparation to absorb water vapor and cause increased volume of preparations.

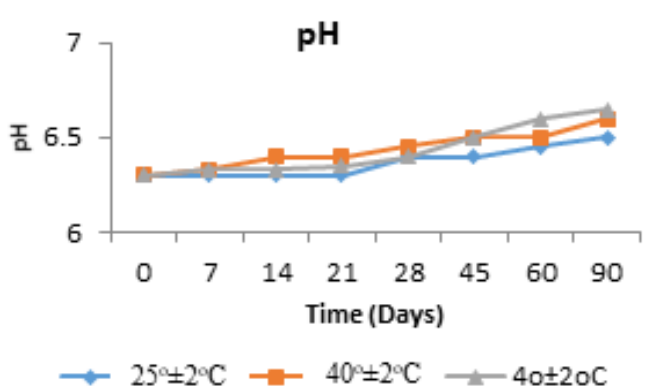

\subsection{Result of $\mathrm{pH}$ measurement}

The $\mathrm{pH}$ of emulgel preparation that has been made were still on safe level for skin topical requirements which was at the range 4.5-6.813. The measured values are presented
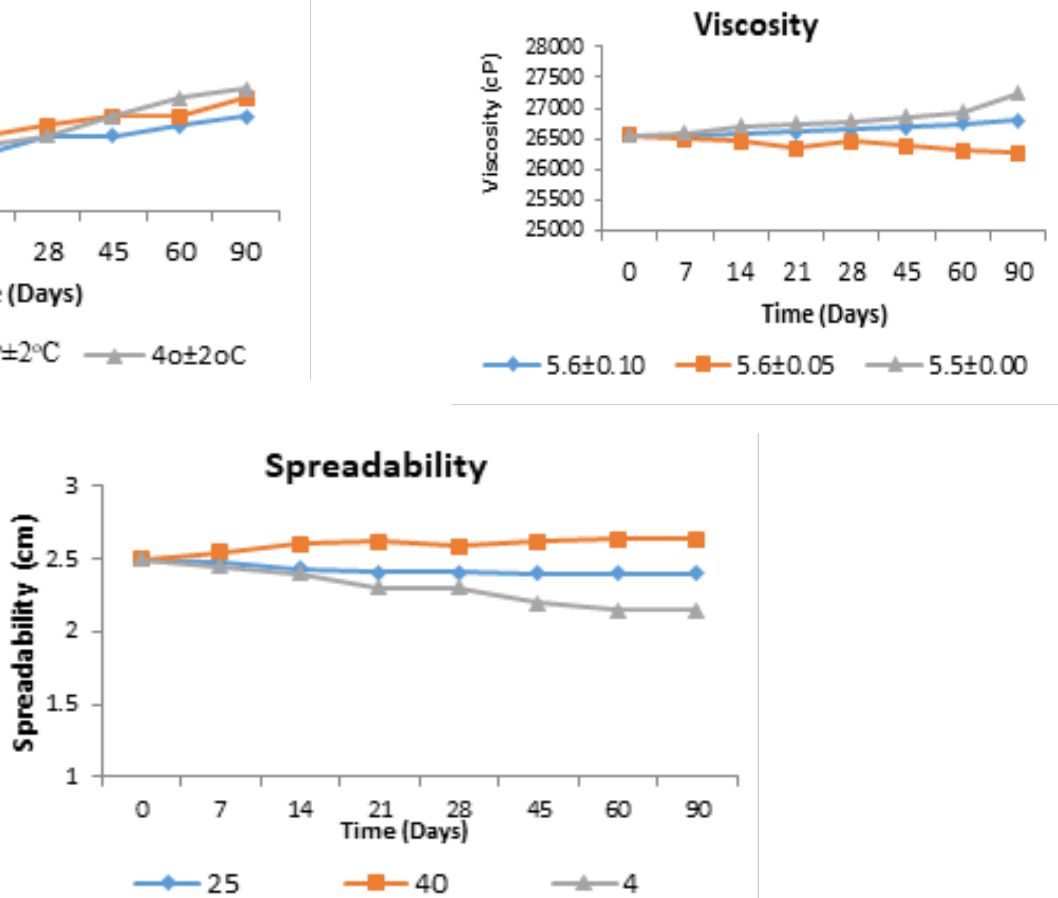

Figure 2. Stability Study of promising formula F5 during storage time at ambient temperature $\left(25^{\circ} \mathrm{C} \pm 2^{\circ} \mathrm{C}\right)$, at climatic chamber $\left(40^{\circ} \mathrm{C} \pm 2^{\circ} \mathrm{C}\right)$, and at cold temperature $\left(4^{\circ} \mathrm{C} \pm 2^{\circ} \mathrm{C}\right)$ 
in figure 2 that indicated the suitable of emulgel for topical application.

\subsection{Result of spreadability measurement} The result of spreadability measurement during storage time was shown on figure 2 . Spreadability it is observed that by increasing viscosity spreadability is decreased. The spreadability value at room temperature storage is more stable than that stored at high temperature at climatic chamber and at cold temperature.

The data are given as the mean and standard deviation of each parameter at each temperature and after each storage period. All results were compared by analysis of variance (ANOVA) for a 95\% confidence level to identity significant difference.

\section{Conclusion}

This research shows that emulgels based on carrageenan as the gelling agent with of active ingredient Tocopherol acetate. Form this research we can also know that promising formula F5 emulgel preparation that are consist of concentration carrageenan $1 \%$, tocopherol acetate $5 \%$, tween 20 and span 20 (1 and $1.5 \%$ ), liquid paraffin $7.5 \%$, propylene glycol 10\%, propyl and methyl paraben $(0.01 \%$ and $0.03 \%)$, tri ethanol amien $2 \%$ has better pharmaceutical requirement from the others formulas and stable during strorage at ambient temperature, at climatic chamber and at cold temperature without any signifycant stability problems.

\section{References}

1. Kagan V, Witt E, Goldman R, Scita
G, Parker L. Ultraviolet light-induced generation of vitamin $\mathrm{E}$ radicals and their recycling. A possible photosensitizing effect of vitamin E in skin. Free Radic Res Commun. 1992;16(1);51-64.

2. Baibhav J, Gurprect, Singh. Emulgel : A Comprehensive Review on The Recent Advances in Topical Drug Delivery. Int. Research J. of Pharm. 2011;2(11);66-70.

3. Kayaa AOW, Suryani A, Santoso J, Rusli MS. The Effect of Gelling Agent Concentration on the Characteristic of Gel Produced From the Mixture of Semirefined Carrageenan and Glukomannan. International Journal of Sciences: Basic and Applied Research (IJSBAR). 2015;20(1);313-24.

4. Distantina S, Wiratni, Fahrurrozi M, Rochmadi. Carrageenan properties extracted from Euchema cotonii, Indonesia. World Academy of Science, Engineering and Technology. 2011;54;738-42.

5. Campo VL, Kawano, D.F, da Silva Jr, D.B, Carvalho, I. Carrageenan: biological properties. Chemical modifications and structural analysis -a review. Carbohydrate Polymers. 2009;77;167-80.

6. Valenta C, Schultz K. Influence of Carrageenan on The Rheology and Skin Permeation of Microemulsion Formulations. Journal of Controlled Release. 2004;95;257-65.

7. Patel J, Trivedi J, Chudhary DRS. Formulation and Evaluation Of Diacrein Emulgel For Psoriatic Arthrities. IJPRBS. 2014;3(2);625-38.

8. V Naga Sravan Kumar Varma et al. Calcipotriol delivery into the skin as emulgel 